\title{
An Empirical Test of Differential Association Theory*
}

\author{
Albert J. Reiss, JR., ANd A. Lewis Rhodes \\ The University of Michigan
}

\begin{abstract}
The main empirical question for this paper is whether boys in close friendship groups have the same specific patterns of delinquent behavior. The delinquent behavior of boys in close friendship triads was compared with that expected for six kinds of delinquent behavior. Two ways of accounting for the observed distribution were examined, one based on a random model and the other on a deduction from differential association theory. We conclude that the probability of an individual committing a specific kind of delinquent act depends upon the commission of the act by other members of the triad, though this is not independent of the social class of boys. The actual delinquent behavior of boys in triads departs somewhat less from the random than the differential association hypothesis, at least for the more serious offenses.
\end{abstract}

$A$ BASIC postulate in sociological writing about delinquents is that delinquent behavior is essentially group behavior. Sociologists have shown that groups enter into delinquent activity in a number of ways. Breckinridge and Abbott were among the first to point out that not only are most delinquent offenses committed in groups but that most lone offenders are influenced by companions. ${ }^{1}$ Somewhat later, Shaw and Meyer ${ }^{2}$ and Shaw and $\mathrm{McKay}^{3}$ estimated the extent to which

* We wish to thank Otis Dudley and Beverly Duncan, Lloyd E. Ohlin and Guy E. Swanson for critical comments and suggestions.

Sophonisba P. Breckinridge and Edith Abbot, The Delinquent Child and the Home, New York: The Russell Sage Foundation, 1917, pp. 34-35.

"Clifford R. Shaw and Earl D. Meyer, "The Juvenile Delinquent," in The Illinois Crime Survey, Illinois Association for Criminal Justice, 1929 , p. 662.

'Clifford R. Shaw and Henry D. McKay, "Social Factors in Juvenile Delinquency: A Study of the Community, the Family, and the Gang in Relation to Delinquent Behavior," National Commission on Law Observance and Enforcement, Report on the Causes of Crime, Washington, D. C. : USGPO, 1931, Volume II, No. 13, Chapter VI, esp. pp. 194-199. juvenili delinquency is group activity, showing that less than 20 percent are lone offenders in juvenile court samples. Shaw and McKay also showed that the modal size of offending groups is two and three participants, and that not all group delinquency is committed by well organized gangs. ${ }^{4}$ More recently Enyon and Reckless demonstrated that companionship is usually present at the onset of admitted delinquency as well as in officially recorded delinquency. 5 These studies for the United States and similar ones in other countries clearly establish that most delinquent behavior is committed as group activity.

Following Sutherland, many sociologists reason that delinquent behavior is genetically a function of learning delinquency through association with delinquents within intimate personal groups.

- Ibid., p. 195.

- Thomas G. Enyon and Walter C. Reckless, "Companionships at Delinquency Onset," The British Journal of Criminology, 2 (October, 1961), 167-68.

- Albert Cohen, Alfred Lindesmith and Karl Schuessler, The Sutherland Papers, Bloomington: Indiana University Press, 1956, pp. 8-11. 
That this hypothesis is not demonstrated is troublesome to some sociologists ${ }^{7}$ and a basis for criticism by others. ${ }^{8}$ Criticism of the hypothesis rests on a logical argument that empirical evidence of association in delinquent acts merely demonstrates concomitance of behavior, whereas a temporal sequence of the effects of association must be demonstrated. ${ }^{9}$

It is one thing to demonstrate that most delinquents associate with other delinquents, participate with them in delinquent activity or are members of a group where others are delinquent and that conforming boys and girls generally associate with other conformers, or belong to groups where behavior is essentially conforming to societal norms. It is quite another to demonstrate that delinquent behavior occurs after induction into a delinquent group, or that delinquency occurs as group activity after a group is formed. Apart from the methodological issues raised by a causal demonstration of group effects on individual behavior and the nature of criteria for an adequate test of differential association theory, there are problems of conceptualizing group effects and operationalizing concepts in differential association theory.

\section{Testing The Theory}

Sutherland never explicitly formulated his hypothesis of differential association

${ }^{7}$ Donald R. Cressey, "Epidemiology and Individual Conduct: A Case from Criminology," Pacific Sociological Reviczo, 3 (Fall, 1960), and James F. Short, Jr., "Differential Association as a Hypothesis: Problems of Empirical Testing," Social Problems, 8 (Summer, 1960), pp. 14-25.

The most pointed criticism has been made by the Gluecks. Sheldon and Eleanor Glueck, Unravcling Juvenile Delinquency, Cambridge: Harvard University Press, 1950, pp. 146-149 and 163-164. See also Marshall Clinard, "Criminological Research," in Robert K. Merton, Leonard Broom and Leonard S. Cottrell, Jr. (eds.), Sociology Today: Problems and Prospects. New York: Basic Books, Inc., 1959, Chapter 23.

- Sheldon Glueck, "Theory and Fact in Criminology," British Journal of Delingucncy, 7 (July, 1956), 92-109. in operational terms and Short questions whether it lends itself to operationalization without reformulation. ${ }^{10}$ Short, however, devised a test of differential association theory to show that the frequency, duration, priority and intensity of association with delinquent and anti-delinquent culture and behavior varies among delinquent and nondelinquent groups. He defined intensity of asociation as a subject's perception of the delinquency of his best friends and concludes that, among his operational measures of differential association, this measure of intensity is most consistently and strongly related to the delinquency of youth. ${ }^{11}$ Short's test rests on a subject's definition of best friends as delinquent. The main purpose of this paper is to make a test similar to Short's on the effect of intensity of association, using, however, data on the actual delinquency known and reported by a boy and his best friends. We propose to examine whether the probability of an individual engaging in several different kinds of delinquent acts is associated with his close friends also having engaged in these acts. It should be apparent that a failure to demonstrate that one's close friends have delinquent behavior patterns similar to one's own in no way contradicts or supports the hypothesis that most delinquent behavior occurs as group activity. Rather, it would simply put in doubt the judgment that boys who engage in a kind of delinquent activity are generally also in intimate association with one another.

Sutherland's differential association hypothesis holds that variation in frequency, duration, priority and intensity of association with delinquent behavior patterns accounts for delinquent behavior. The homophily hypothesis holds that one is likely to select as best friends those whose values and behavior are similar to one's own ${ }^{12}$ while coalition theory argues that

\footnotetext{
${ }^{20}$ James F. Short, Jr., op. cit., p. 17.

"James F. Short, Jr., op. cit., p. 18.

1 Paul F. Lazarsfeld and Robert K. Merton, "Friendship as Social Process: A Substantive and Methodological Analysis," in Morroe Berger, et. al., Frcidom and Control in Modern
} 
all other things being equal, constraints on members who deviate from the expectations of the group lead to their behaving in conformity with these standards. ${ }^{13}$ Though not explicitly stated in any theory, both group selection and group constraint hypotheses lead to the same conclusion: one's close friends should have a delinquency history similar to one's own.

It is apparent, however, that there is considerable variation over time in the cliques to which an adolescent belongs, in whom he will select as his best friends, and in the kinds of delinquent activity in which he will engage. Shaw pointed out, for example, that Sidney in the course of his delinquent career from 7 to 17 years of age was officially known to have been involved in delinquency with 11 different companions, representing three distinct groups whose activities and traditions were delinquent in character, and that he was never implicated in any offense with more than three delinquents. ${ }^{14}$ Recognizing that current best friends are not necessarily companions from past delinquent association, it seems consistent with differential association theory to argue that, if current best friends comprise a salient primary group, and if past behavior serves as a basis for mutual communication and action within it (which it need not), then boys currently in intense association with one another should show similar patterns of delinquency. Assuming that specific tecliniques for committing delinquent acts are communicated in primary association, it follow's that all, or none, of the boys in close friendship triads should report committing a given kind of offense. Within

Society, New York: D. Van Nostrand Co., Inc., esp. footnote 19.

13 John W. Thibaut and Harold H. Kelley, The Social Psychology of Groups, New York: John W. Wiley, Inc., 1959, pp. 208 and 210, and L. Festinger and J. Thibaut, "Interpersonal Communication in Small Groups," Journal of Abnormal and Social Psychology, XLVI (1951), 92-100.

${ }^{24}$ Clifford R. Shaw and Henry D. McKay, op. sit., p. 221. a triadic friendship group, there should be no dyads committing a given type of offense, since group constraint should produce homogeneity in behavior. It should be clear that whether or not boys in close friendship groups show similarity in delinquent behavior because they select one another on this basis, or as a result of association, failure to show that delinquency histories of boys in close friendship groups are the same casts doubt at least upon the specificity of any learned delinquent behavior in intense association with others. Since Sutherland did not restrict his hypothesis to lower class delinquents, behavioral homophily should hold regardless of social class. ${ }^{15}$

To show that one's close friends are also delinquent is not to show that they have an effect on all of one's delinquent activity. Shaw and McKay early showed that stealing is more likely to be a group offense than are offenses against the home and school. ${ }^{16}$ Enyon and Reckless have gone further to show that companionship characterizes first participation in some kinds of offenses more than in others. Companions were present in 100 per cent of boys' first involvement in gang fights but only 56 per cent of the cases of first running away from home. ${ }^{17}$ While our study cannot demonstrate the precisc effect of friendship on delinquency patterns, it investigates the extent to which there is covariation in a boy's delinquent behavior and that of his friends for different kinds of delinquent behavior.

Sociological theories on delinquent subcultures that are consistent with Sutherland's differential association hypothesis postulate that members of delinquent subcultures become highly dependent upon one another, particularly for status gratification. As Short points out, it follows that members of such groups, having a

\footnotetext{
"The Sutherland Papers, op. cit., p. 19, pp. 32-33 and pp. 58-59.

${ }^{20}$ Clifford R. Shaw and Henry D. McKay, op. cit., pp. 195-196.

${ }^{17}$ Thomas G. Enyon and Walter C. Reckless, op. cit. Table 3, p. 170.
} 
more intense association with one another, should show greater similarity in their patterns of delinquency than do members of other delinquent groups. ${ }^{18}$ Cohen's general theory of delinquent subcultures holds that subcultural delinquent groups should be homogeneous in behavior for a variety of delinquent offenses against property and persons. It is implicit in his theory that middle class boys will show less similarity and versatility in their delinquency. ${ }^{\mathbf{1 9}}$ Miller holds that delinquency is endemic in lower class culture. It would be consistent with his theory to argue that delinquent behavior of lower class boys is independent of the commission of the act by other members of the group. ${ }^{20}$

\section{THE INVESTIGATION}

The investigation was designed to gather information on the actual delinquent behavior of boys in close friendship cliques. A sample of 378 boys was drawn from a base population of all white males between the ages of 12 and 16 who were registered in one of 45 public, private or parochial junior or senior high schools in Davidson County, Tennessee during the 1957 school year. Strata were designed so as to select disproportionately lower- and middle-class delinquent boys. ${ }^{21}$

Each clique is a triad composed of a boy selected in the stratified probability

\footnotetext{
${ }^{18}$ James F. Short, Jr., op. cit., p. 17.

- Albert K. Cohen, Delinquent Boys: The Culture of the Gang, Glencoe: The Free Press, 1955, pp. 157-169.

"Walter Miller, "The Impact of a "Total Community' Delinquency Control Project," Social Problems, 10 (Fall, 1962), 169-191.

n This is a more efficient sample design inasmuch as delinquency is a relatively low incidence phenomenon in the general population. The methodological problems encountered in dealing with a low incidence phenomenon in a population have been discussed in Daniel Glaser, "Differential Association and Criminological Prediction," Social Problems, 8 (Summer, 1960), p. 7, and Albert J. Reiss, Jr., "Unraveling Juvenile Delinquency II: An Appraisal of the Research Methods," American Journal of Sociology, 57 (September, 1951), 118-119.
}

sample of 378 boys and his two closest friends. Given a large population from which the sample of boys was drawn, only a few sample cases chose the same "closest" friend. Effects of overlapping friendship choice or of pyramiding therefore are negligible. Information was gathered for 299 triads and 79 dyads. The dyads are pairs where a boy selected only one "best friend." Data are presented in this paper only for the 299 triads. Each step was replicated for the 79 dyads and the results are similar where the number of dyads makes comparison possible.

The index person in each triad was classified into one of seven conforming or delinquent types. ${ }^{22}$ The career-oriented delinquent is the most delinquent person in the classification schema. He is oriented toward the adult criminal world and maintains contact with adult criminals. The largest group of delinquents are peer-oriented and directed in their goals and behavior. The lone delinquent is our nonconforming isolate. There are four types of conforming boys. The conforming nonachiever is comparable to William Whyte's "corner boy" and the conforining achiever to his "college boy," if social class attributes are disregarded. ${ }^{23}$ The hyperconformer disregards conventional for strict conformity while the conforming isolate is outside the clique system. Peer-oriented delinquents, conforming nonachievers, and achievers are divider into white-collar and blue-collar status based on father's occupation. ${ }^{24}$

The dependent variable, self-reported delinquent behavior, was measured by asking each boy how often he had done any of the following things, whether alone or with others, and by inquiring about the conditions related to it: taken little things worth less than $\$ 2$ ? $\$ 2$ to $\$ 50$ ?

\footnotetext{
${ }^{22}$ Albert J. Reiss, Jr. and A. Lewis Rhodes, "The Distribution of Juvenile Delinquency in the Social Class Structure," American Sociological Revicze, 26 (October, 1961), Chart I.

William F. Whyte, Strect Corner Society, Chicago: University of Chicago Press, 1937.

"Albert J. Reiss, Jr. and A. Lewis Rhodes, op. cit., pp. 721-722.
} 
more than $\$ 50$ ? purposely damaged or destroyed property? taken a car without the owner's permission or knowledge? beat up somebody bad enough to be arrested ? ${ }^{25}$ Self-reports include virtually all cases of officially recorded delinquency. Only delinquent acts committed after age 10 are data for this paper.

Self-reported delinquent acts were tabulated for each of the six categories of delinquent act for the 299 triads arranged in the 10 types of conformingdelinquent, SES groups. ${ }^{26}$ This tabulation provided information on kind of delinquent behavior reported by none, one, two or all members of the triad in each of the 10 conforming-delinquent groups. A model was then constructed to give the expected delinquent behavior composition of the triad, using the actual rate of delinquency for the sample of boys for estimation purposes. The model is based on the expansion of the binomial. ${ }^{27}$ Our use of the binomial ignores variability in response patterns by friendship choice, e.g. + (original) - (first best friend) + (second best friend) and ++- or -++ are all treated as two boys expected (or actual) to commit the act. This disregard of response order seams warranted for we cannot determine whether the original subject models his behavior on that of his two closest friends, or whether he chooses friends who have similar behavior, or whether they copy his behavior.

The observed distribution of boys in

${ }^{x}$ Readers will note the similarity of these questions with the Nye-Short delinquency scale items: Ivan F. Nye and James F. Short, Jr., "Scaling Delinquent Behavior," Amcrican Sociological Revieze, 22 (June, 1957), 326-331.

* The authors express their appreciation to NAL, State University of Iowa for use of the IBM 650. A special program for rapid tabulation of response patterns in triads was developed for this study.

$$
{ }^{\prime} f(x)=\left(\frac{3 !}{x !(3-x) !}\right) p^{x}(a)^{2-x}
$$

where $x$ is the number of boys expected to commit the act $(0,1,2$ or 3$)$; p is the proportion of the subgroup reporting commission of the act; $a$ is the proportion of the subgroup not reporting commission of the act. triads reporting they committed an act of delinquency is then compared with the expected distribution. The chi square test of goodness of fit is used to test the significance of the departure of the observed measure from the hypothetical one of the binomial. ${ }^{28}$ Occasionally, the conventional test of the significance of difference between two proportions is used to test whether there is any significant difference in the number of observed and expected triads where all members of the triad reported committing the act.

Very briefly, this paper attempts to shed light on three closely related questions that are germane to propositions about the group nature of delinquency and the empirical testing of differential association theory: (1) Does the probability of an individual committing kinds of delinquent acts depend upon his close friends comitting these acts? (2) Is there variation in dependence upon friends committing delinquent acts among different kinds of delinquent behavior? (3) Is the probability of committing a delinquent act less dependent upon one's friends committing the act in some kinds of conforming or delinquent groups than in others?

\section{Findings}

Boys generally choose boys as close friends whose law-abiding or delinquent behavior is similar to their own. Table 1 answers our first question in comparing reported delinquent behavior of boys in triads with that expected from the proportion of boys in the sample who reported committing specific kinds of delinquency. For each kind of delinquent behavior, the probability of an individual committing a specific delinquent act depends upon the commission of the act by other members of the friendship triad. More of the triads in Table 1 than expected from the binomial are made up of boys, all or none of whom engaged in

\footnotetext{
"No test was made if the expected frequency in any cell was less than two or less than five in two cells of a $2 \times 3$ table.
} 
the same kind of delinquent act. The more serious the offense, the greater the difference between observed and expected proportions of triads where all of the boys committed the same kind of delinquent offense. Confidence in the finding that the probability for a boy committing a delinquent act is not independent of the behavior of his close friends is increased with the observation that fewer of the triads than expected have only one boy reporting he engaged in the delinquent activity. Table 2 restates the conclusion in a way that aids the interpretation.

\section{TABLE 1}

Observed ( $f$ ), Expected $\left(f_{e}\right)^{1}$ and Sum of Expected $\left(f_{\Sigma}\right)^{2}$ for Conforming-Delinquent Subgroups. Number of White Male Triads Classified by Number of Males in Each Triad Who Reported Delinquent Behavior One or More Times for Six Kinds of Delinquent Behavior

\begin{tabular}{|c|c|c|c|c|c|c|c|}
\hline \multirow{2}{*}{$\begin{array}{c}\text { Kind of } \\
\text { Delinquent } \\
\text { Behavior }\end{array}$} & \multirow{2}{*}{$\begin{array}{c}\text { Per Cent } \\
\text { Reporting } \\
\text { Behavior } \\
\end{array}$} & \multicolumn{4}{|c|}{$\begin{array}{c}\text { Number in Triad Reporting } \\
\text { Delinquent Behavior }\end{array}$} & \multirow{2}{*}{$\begin{array}{c}\text { Number } \\
\text { of } \\
\text { Triads }\end{array}$} & \multirow[b]{2}{*}{$P\left(x^{2}\right)$} \\
\hline & & 0 & 1 & 2 & 3 & & \\
\hline Auto theft & 12 & & & & & & \\
\hline $\mathbf{f}_{\mathbf{e}}$ & & 204 & 83 & $11^{*}$ & $1^{*}$ & 299 & $<.001$ \\
\hline $\mathbf{f}$ & & 229 & 42 & 17 & 11 & 299 & \\
\hline$f_{2}$ & & $22 i$ & 43 & 19 & 10 & 299 & \\
\hline Theft over $\$ 50$ & 12 & & & & & & \\
\hline$f_{e}$ & & 204 & 84 & $11^{*}$ & $1^{*}$ & 299 & $<.001$ \\
\hline f & & 236 & 31 & 18 & 14 & 299 & \\
\hline $\mathbf{f}_{\mathbf{I}}$ & & 232 & 37 & 19 & 11 & 299 & \\
\hline Theft: $\$ 2-\$ 50$ & 18 & & & & & & \\
\hline$f_{e}$ & & 111 & 130 & 51 & 7 & 299 & $<.001$ \\
\hline$f$ & & 161 & 65 & 36 & 37 & 299 & \\
\hline$f_{z}$ & & 150 & 78 & 44 & 27 & & \\
\hline Assault & 28 & & & & & & \\
\hline$f_{e}$ & & 168 & 107 & $23^{*}$ & $2^{*}$ & 299 & $<.001$ \\
\hline f & & 200 & 61 & 18 & 20 & 299 & \\
\hline $\mathbf{f}_{\boldsymbol{z}}$ & & 189 & 74 & 26 & 10 & 299 & \\
\hline Vandalism & -0 & & & & & & \\
\hline$f_{e}$ & & 44 & 116 & 103 & 31 & 294 & $<.001$ \\
\hline$f$ & & 75 & 84 & 78 & 57 & 294 & \\
\hline$f_{\mathbf{z}}$ & & 60 & 103 & 86 & 45 & 294 & \\
\hline Theft under $\$ 2^{4}$ & 一 & & & & & & \\
\hline $\mathbf{f}_{\mathbf{e}}$ & & 27 & 98 & 120 & 49 & 294 & $<.001$ \\
\hline$f$ & & 52 & 80 & 77 & 85 & 294 & \\
\hline$f_{\Sigma}$ & & 42 & 88 & 97 & 67 & 294 & \\
\hline
\end{tabular}

${ }^{2}$ Expected frequencies are calculated for the binomial using the proportion of boys in the sample who reported committing each kind of delinquency.

Expected frequencies were calculated for the binomial for each of 10 conforming-delinquent subgroups. The sum of these expected values is reported here.

- $x^{2}$ computed for actual (f) with expected $\left(f_{e}\right)$ values only.

- Offense committed two or more times.

* Cell frequencies combined for computation of $\chi^{2}$. 
For each kind of act, significantly more of the original sociometric subjects who reported the offense, than of those who did not, have friends who also committed the act.

Nonetheless, Tables 1 and 2 make apparent considerable variation in delinquent behavior homophily of close friendship triads. Of the triads in Table 1 where at least one boy reported committing auto theft or assault, three-fifths have only one boy reporting he committed the act. By way of contrast, but one-fourth of the triads where at least one boy committed an act of vandalism and one in five for petty larceny are made up of boys where only one reported committing the act. Original sociometric subjects in Table 2 are more likely to choose boys as friends

\section{TABLE 2}

Per Cent of Triads with Number of Friends Committing Delinquent Act by Original Subject's Delinquent Behavior, for Six Kinds of Delinquent Behavior

\begin{tabular}{|c|c|c|c|c|c|}
\hline \multirow{2}{*}{$\begin{array}{l}\text { Original } \\
\text { Subject's } \\
\text { Delinquent } \\
\text { Act }\end{array}$} & \multicolumn{4}{|c|}{$\begin{array}{l}\text { Number of } \\
\text { Friends Comming } \\
\text { Same Kind of Act }\end{array}$} & \multirow[b]{2}{*}{$P\left(x^{3}\right)$} \\
\hline & 0 & 1 & 2 & Total & \\
\hline \multicolumn{6}{|c|}{ Auto theft } \\
\hline Yes & 45 & 28 & 27 & 40 & .001 \\
\hline No & 88 & 9 & 3 & 259 & \\
\hline \multicolumn{6}{|c|}{ Theft over $\$ 50$} \\
\hline Yes & 29 & 29 & 42 & 34 & .001 \\
\hline No & 89 & 8 & 3 & 265 & \\
\hline \multicolumn{6}{|c|}{ Theft: $\$ 2-\$ 50$} \\
\hline Yes & 24 & 32 & 44 & 84 & .001 \\
\hline No & 75 & 21 & 4 & 215 & \\
\hline \multicolumn{6}{|l|}{ Assault } \\
\hline Yes & 35 & 27 & 38 & 52 & .001 \\
\hline No & 81 & 17 & 2 & 247 & \\
\hline \multicolumn{6}{|c|}{ Vandalism } \\
\hline Yes & 16 & 41 & 43 & 134 & .001 \\
\hline No & 47 & 39 & 14 & 160 & \\
\hline \multicolumn{6}{|c|}{ Theft under $\$ 2$} \\
\hline Yes & 9 & 37 & 54 & 158 & .001 \\
\hline No & 38 & 48 & 14 & 136 & \\
\hline
\end{tabular}

who also committed acts of vandalism or theft under two dollars than they are to have chosen boys as friends who also committed acts of auto larceny or assault, when they report having done these things. We must conclude in answer to our second question that although, in the aggregate, commission of a kind of delinquent act is not independent of the commission of the act by other members of a close friendship triad, the correlation varies with kind of delinquent behavior and is far from perfect for any kind.

We know from previous studies that roughly four-fifths of all boys arrested for delinquency had associates in the offense for which they were arrested, and that at least that high a proportion of delinquent boys have as close friends boys who have committed some kind of delinquent act. We must conclude then, that close friendship choices are more closely correlated with delinquency per se than with specialization or engagement in all specific kinds of delinquency.

Attention has been called to the ambiguity in formulation of Sutherland's differential association theory rendering difficult both operationalization of the theory and deductions from it. An altogether literal deduction from Sutherland's theory, though he never made it, is that either all or none of the boys in a close friendship triad should report committing the same kind of offense. It is immediately apparent from inspection of Tables 1 and 2 that there is a substantial number of triads where only one or two members of the triad committed the same kind of delinquent act, thereby calling into question any postulate about the homogeneity of law-violative behavior in triads through differential association. Let us assume, however, as does a variant of coalition theory, that when two members of a triad engage in a given kind of behavior, the third member is under strong pressure to do likewise. ${ }^{28}$ We would expect, then, that there should be relatively few, if any, close friendship triads with

\footnotetext{
See footnote 13 .
} 
only two members engaging in delinquent behavior. Expressing the triads where all members commit the same kind of delinquent act as a per cent of all triads where two or three members commit the act, the following distribution results; auto theft (65 per cent); theft over $\$ 50$ (64 per cent) ; theft $\$ 2-\$ 50$ ( 80 per cent) ; assault ( 83 per cent); vandalism ( 71 per cent); theft under $\$ 2$ ( 82 per cent). The distribution supports the contention that there is pressure toward uniformity of behavior in these triads. In two-thirds or more of the triads, for each kind of delinquent offense, all members report they committed the act, i.e., if more than one did it, it was probably three. There remained, nonetheless, a substantial minority of triads in which only two members committed the same kind of delinquency. The more serious offenses are least likely to show triadic uniformity.

Thus far two main ways of accounting for the observed distribution of delinquent associates in close friendship triads have been introduced. We first examined whether the sample of triads was a sample drawn from a binomial based on the rate of a specified kind of delinquency, and we concluded that the departure of the observed distribution from the binomial exceeded that ordinarily encountered in random sampling. The probability of an individual committing a specific kind of delinquent act depends upon the commission of the act by other members of the friendship triad. We then examined whether the sample of triads conformed to predictions from Sutherland's differential association theory or coalition theory. Inasmuch as there was a substantial number of triads with only one or two members reporting they engaged in a specific kind of delinquent behavior, we are led to question the postulate that differential association is a necessary and sufficient condition explaining delinquency. Table 3 summarizes these comparisons and is a convenient way of raising the further question whether the observed distribution of triads departs more from the random distribution than the expected one based on the differential association hypothesis. Although no test of statistical significance is employed, it

\section{TABLE 3}

Comparison of Reported Behavior in 299 Delinquent Triads (f) with Random Expectation $\left(f_{e}\right)$ and Number Expected under Differential Association Effect on Behavior of Original Member of Sociometric Triad $\left(\mathrm{f}_{\mathrm{d}}\right)^{2}$ for Six Kinds of Delinquent Behavior

\begin{tabular}{|c|c|c|c|}
\hline $\begin{array}{l}\text { Type of Delinquency } \\
\text { 2nd Number in Triad } \\
\text { Committing Act }\end{array}$ & $f_{0}$ & $f$ & $\mathbf{f}^{\mathbf{a}}$ \\
\hline \multicolumn{4}{|l|}{ Auto theft } \\
\hline 3 & * & 11 & 40 \\
\hline 2 or 1 & 95 & 59 & 0 \\
\hline 0 & 204 & 229 & 259 \\
\hline \multicolumn{4}{|l|}{ Theft over $\$ 50$} \\
\hline 3 & * & 14 & 34 \\
\hline 2 or 1 & 95 & 49 & 0 \\
\hline 0 & 204 & 236 & 265 \\
\hline
\end{tabular}

Theft: $\$ 2-\$ 50$

$\begin{array}{lrrr}3 & 7 & 37 & 84 \\ 2 \text { or } 1 & 181 & 101 & 0 \\ 0 & 112 & 161 & 215\end{array}$

Assault

$\begin{array}{lrrr}3 & 2 & 20 & 52 \\ 2 \text { or } 1 & 129 & 79 & 0 \\ 0 & 168 & 200 & 247 \\ \begin{array}{l}\text { andalism } \\ 3\end{array} & 121 & 138 & 220 \\ 2 \text { or } 1 & 172 & 151 & 0 \\ 0 & 5 & 10 & 79\end{array}$

Theft under $\$ 2$

\begin{tabular}{lrrr}
3 & 49 & 85 & 158 \\
2 or 1 & 218 & 157 & 0 \\
0 & 27 & 52 & 136 \\
\hline
\end{tabular}

${ }^{1}$ The proportion of boys in the sample who reported each kind of delinquency is used to set up the binomial of triads.

The expected values for differential association are the marginal frequencies of original subjects committing and not committing a specific kind of delinquent act.

* Less than one case. 
seems clear that the observed distribution is closer to the binomial than to the expected distribution based on the differential association hypothesis.

The reciprocation of sociometric choices, the delinquency orientation and behavior of boys chosen as close friends, and the content and seriousness of a boy's delinquent offenses were the main criteria in classifying a boy into a particularly conforming or delinquent type in our study. The type and content of the delinquent offenses of his close friends were not used as criteria in classifying a boy into a particular group. Although classification of a boy and his friends into a conforming or delinquent subtype then is not independent of classification by type of delinquent behavior, there still can be considerable variation in the delinquent behavior among the members of a triad within any kind of delinquent group. Given the possibility of variation in type and content of delinquent offense within a triad, we compared the triads in each subtype of conforming or delinquent group to see whether boys in each subtype chose as close friends boys who committed acts of delinquency similar to their own. Table 4 compares the reported behavior of boys in each subtype of conforming or delinquent triad with the behavior expected from the proportion of boys in each type who reported committing each kind of act. Such comparisons should permit us to learn whether membership in a specific kind of conforming or delinquent group has any effect upon one's delinquent behavior independent of the rate of delinquency within that type of group.

Inspection of Table 4 shows that there is little significant variation between observed and expected values for any of the conforming-delinquent groups. The answer to our third question then is that selection of close friends who commit a specific kind of act within a given type of conforming-delinquent group is largely a function of the rate of that kind of delinquency within each group. The more boys there are committing any kind of offense in a type of group, the more likely one is to have groups in which all members commit that kind of offense. Put in another way, our classification of boys into conforming and delinquent types of groups accounts in large part for the tendency for boys to choose as close friends boys who commit delinquent acts similar to their own. This can be seen by turning again to Table 1 where we observe that the sum of the expected values for the conforming-delinquent subgroups is remarkably like that observed for all triads, particularly for the serious offenses of auto theft and theft over $\$ 50$. These two types of offenses are more clearly concentrated in the career-and peer-oriented delinquent types, of course. The similarity between the sum of the expected values for subgroups and the actual behavior reported within triads is less marked for the less serious offenses, offenses which occur quite frequently in most conforming and delinquent groups.

These observations (a summary of which is aided by comparing the $f$ and $f_{\Sigma}$ values in Table 1 ) suggest that a model of random selection accounts for subcultural or career-oriented delinquents associating most frequently with boys who commit delinquent acts similar to their own, given our classification of them into that type of delinquent group. This finding, of course, should not obscure the fact that the classification system does discriminate among types of conforming and delinquent boys. Career-oriented delinquents are easily distinguished from all other types by the fact that for every kind of offense, at least two-thirds of the triads are made up of boys who committed the same kind of offense. There are significantly more career-oriented triads in which all members engaged in every kind of offense than in any other type of delinquent group except that pecroriented white-collar delinquents have significantly more triads in which all members committed theft under two dollars. 


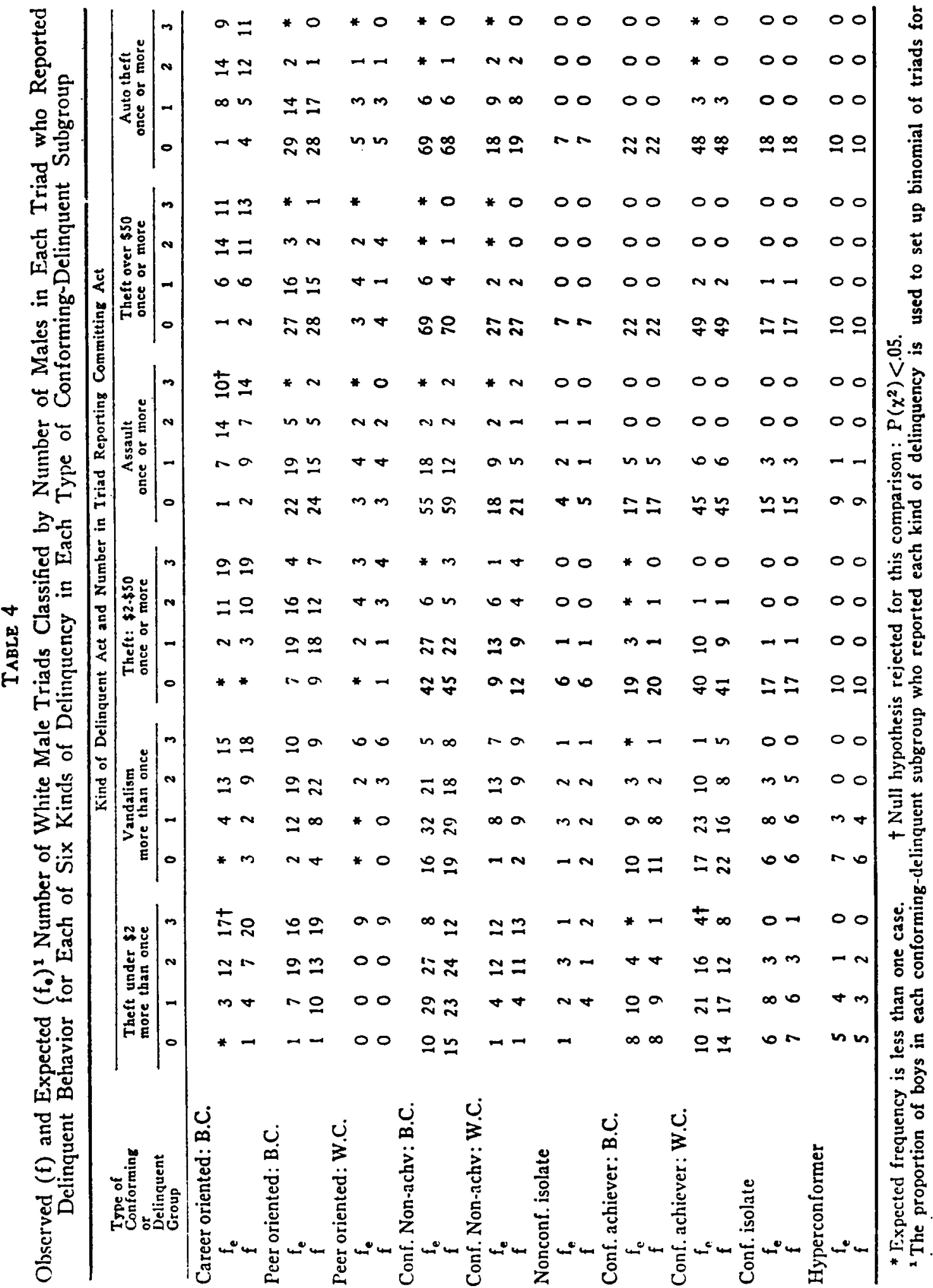


We have shown that for each kind of delinquent behavior reported in this study, the probability of an individual committing a specific act of delinquency is dependent upon the commission of the act by other members of the triad. Except for Sutherland's original formulation of differential association theory, most contemporary sociological theories emphasize a qualitative difference between middle and lower class delinquency. In Table 5 we ask whether the finding that a boy's delinquent behavior depends upon his close friends engaging in it is independent of the social class status of the boys. It clearly is not for all types of offenses. Among blue-collar boys, the probability of a boy engaging in any specific kind of delinquency depends upon his close friends engaging in it but among whitecollar boys this is true only for theft involving amounts of less than $\$ 50$ or for vandalism. Apparently when middle class delinquent boys engage in serious delin-

\section{TABLE 5}

Observed (f) and Expected $\left(f_{e}\right)^{1}$ Number of White Male Triads Classified by Number of Males in Each Triad who Reported Delinquent Behavior for Six Kinds of Delinquent Behavior, Controlling on Social Class of Original Subject in Each Triad

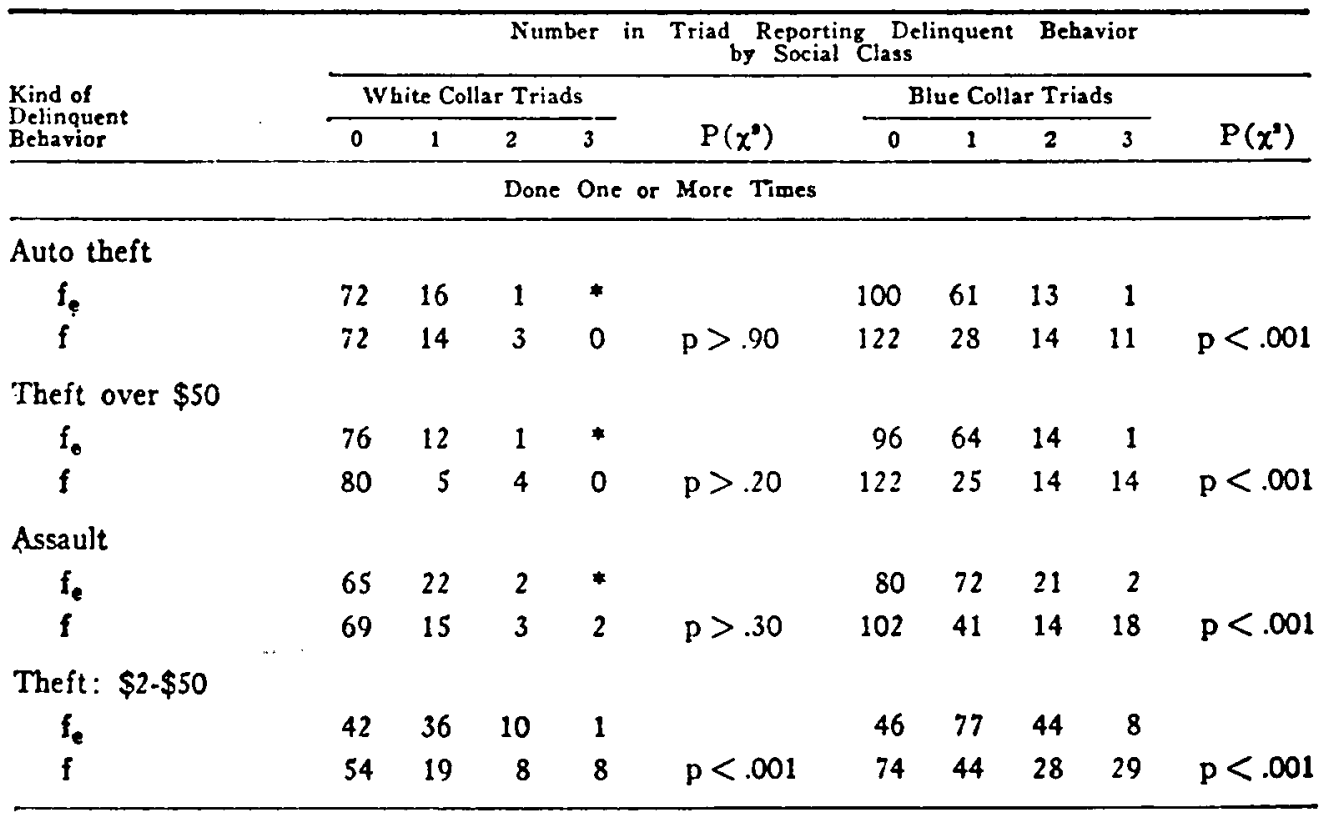

Done More than Once

\begin{tabular}{|c|c|c|c|c|c|c|c|c|c|c|}
\hline \multicolumn{11}{|c|}{ Vandalism } \\
\hline$f_{e}$ & 13 & 36 & 31 & 9 & & 22 & 64 & 64 & 21 & \\
\hline$f$ & 24 & 25 & 20 & 20 & $\mathrm{p}<.001$ & 37 & 47 & 51 & 36 & $\mathrm{p}<.001$ \\
\hline \multicolumn{11}{|c|}{ Theft under $\$ 2$} \\
\hline$f_{e}$ & 6 & 27 & 38 & 18 & & 13 & 52 & 73 & 33 & \\
\hline $\mathbf{f}$ & 15 & 21 & 23 & 30 & $\mathrm{p}<.001$ & 25 & 46 & 48 & 52 & $\mathrm{p}<.001$ \\
\hline
\end{tabular}

* Expected frequency is less than one case.

2 The proportion of boys in each social class subgroup who reported committing each kind of delinquency is used to set up the binomial of triads for cach social class subgroup. 
TABLE 6

Per Cent of Triads Where All Boys Admit Delinquent Acts in Which All Boys Also Indicate Commission of Act with Someone Else, by Kind of Act and Type of Triad

\begin{tabular}{|c|c|c|c|c|c|c|c|c|c|c|c|c|}
\hline \multirow{3}{*}{$\begin{array}{l}\text { T'ype of } \\
\text { Conforming } \\
\text { or } \\
\text { Delinquent } \\
\text { Triad }\end{array}$} & \multicolumn{12}{|c|}{ Kind of Delinquent Act } \\
\hline & \multicolumn{2}{|c|}{$\begin{array}{c}\text { Theft }<\$ 2 \\
\text { once or } \\
\text { more }\end{array}$} & \multicolumn{2}{|c|}{$\begin{array}{c}\text { Vandulism } \\
\text { once or } \\
\text { more }\end{array}$} & \multicolumn{2}{|c|}{$\begin{array}{l}\text { Theft: } \$ 2-\$ 50 \\
\text { once or } \\
\text { more }\end{array}$} & \multicolumn{2}{|c|}{$\begin{array}{l}\text { Assault } \\
\text { once or } \\
\text { more }\end{array}$} & \multicolumn{2}{|c|}{$\begin{array}{l}\text { Theft }>\$ 50 \\
\text { once or } \\
\text { more }\end{array}$} & \multicolumn{2}{|c|}{$\begin{array}{l}\text { Auto Theft } \\
\text { once or } \\
\text { more }\end{array}$} \\
\hline & $\begin{array}{c}\text { Per } \\
\text { Cent }\end{array}$ & Num- $_{\text {ber }}$ & $\begin{array}{l}\text { Per } \\
\text { Cent }\end{array}$ & $\underset{\text { ber }}{N_{\text {um }}}$ & $\begin{array}{c}\text { Per } \\
\text { Cent }\end{array}$ & $\begin{array}{c}\text { Num- } \\
\text { ber }\end{array}$ & $\begin{array}{c}\text { Per } \\
\text { Cent }\end{array}$ & $\underset{\text { ber }}{\text { Num- }}$ & $\begin{array}{l}\text { Per } \\
\text { Cent }\end{array}$ & $\mathrm{N}_{\text {ber }}$ & $\begin{array}{l}\overline{\text { Per }} \\
\text { Cent }\end{array}$ & $\underset{\text { ber }}{\text { Num }}$ \\
\hline Career Oriented: B.C. & 45 & 22 & 86 & 21 & 74 & 19 & 79 & 14 & 100 & 13 & 82 & 11 \\
\hline Peer Oriented: B.C. & 45 & 29 & 74 & 19 & 43 & 7 & 50 & 2 & 0 & 1 & & 0 \\
\hline Peer Oriented: W.C. & $\ddot{2}$ & 9 & 100 & 7 & 75 & 4 & & 0 & & 0 & & 0 \\
\hline Conf. non-achv: B.C. & 32 & 25 & 80 & 20 & 67 & 3 & 0 & 2 & & 0 & & 0 \\
\hline Conf. non-achv: W.C. & 42 & 19 & 92 & 13 & 100 & 4 & 50 & 2 & & 0 & & 0 \\
\hline Non-conf. isolate & 20 & 5 & 100 & 3 & & 0 & & 0 & & 0 & & 0 \\
\hline Conf. achiever: B.C. & 0 & 6 & 80 & 5 & & 0 & & 0 & & 0 & & 0 \\
\hline Conf. achiever: W.C. & 5 & 19 & 80 & 10 & & 0 & & 0 & & 0 & & 0 \\
\hline Conf. isolate & 25 & 4 & 100 & 2 & & 0 & & 0 & & 0 & & 0 \\
\hline Hyperconformer & & 0 & & 0 & & 0 & & 0 & & 0 & & 0 \\
\hline
\end{tabular}

quent behavior it is relatively independent of their close friendship choices.

Our interviews with subjects were structured so as to avoid mention by name of close friends in delinquency. To do so would violate peer norms about "squealers" and at times jeopardize rapport. Many respondents nevertheless volunteered names of their co-participants for delinquent acts in which they had associates and these were usually persons mentioned as "closest friends." Each respondent was explicitly asked for each reported delinquent offense whether he was (always, usually, sometimes or never) alone (or with one or more persons) when committing it. Table 6 presents this information only for those triads in which all members reported committing a specific kind of delinquent act. The objective is to investigate whether unanimous reporting of engaging in a kind of delinquent behavior in a triad means they engaged in the behavior as group activity. Evidently this is not always the case. It is apparent that, for close friendship groups where all members committed the same kind of act, participants are most likely to report vandalism as group activity and least likely to report theft under $\$ 2$ as group activity. This finding is consistent with that of Enyon and Reckless on the percentage of cases in which companions were present at first occurrence of admitted delinquency, it being higher for acts of vandalism ( 91 per cent) than for taking things under $\$ 2$ (69 per cent)..$^{30}$

If attention is directed to variation in group involvement in delinquency among our conforming-delinquent types of triads, there is substantial evidence that only career-oriented delinquents report group involvement for all types of offense other than theft under $\$ 2$. The career-oriented delinquent is apparently most likely to commit his offenses with accomplices.

\section{Summary and Conclusions}

The main question for this paper was whether boys in close friendship groups

- Thomas G. Enyon and Walter C. Reckless, op. cit., Table 4. 
have the same specific patterns of delinquent behavior. The reported delinquent behavior of boys in close friendship triads was compared with that expected for six kinds of delinquent behavior. Two different ways of accounting for the observed distribution were examined.

The first compares the observed delinquent behavior of boys in triads with a binomial based on the rate for each kind of delinquency in the population. We concluded that the probability for an individual committing a specific kind of delinquent act depends upon the commission of the act by other members of the triad. This dependence upon close friends engaging in delinquent activity is not independent of the social class status of boys for all kinds of offenses, however. Among blue-collar boys, the probability of a boy engaging in any of the six kinds of delinquency depends upon his close friends engaging in it but among whitecollar boys this is true only for the less serious offenses.

The second comparison asks whether the behavior of boys in triads departs from predictions from Sutherland's differential association theory or coalition theory that there be uniform conformity in conforming groups and uniformity of specific kinds of delinquent behavior in delinquent groups. We concluded there is considerable departure from this explanatory model even when only those groups are considered where at least two boys engaged in the same kind of delinquency. The observed distribution of delinquency in close friendship triads departs somewhat less from the random than the differential association model, at least for the more serious offenses.

There is in fact considerable variation in the delinquent behavior homophily of friendship triads. The degree to which commission of a kind of delinquent act depends upon its commission by other members of the triad varies considerably by type of delinquency. Vandalism and petty larceny, the more common offenses, are commonly committed by two or three members of the triad while a majority of the triads where at least one member committed auto theft or assault are made up of only one member committing the offense. Behavioral homophily in triads does not mean that boys always or usually commit these offenses together, since there is evidence that theft under $\$ 2$ is least likely to involve group activity. Two things seem evident from these findings, that delinquent behavior homophily in close friendship triads does not necessarily involve association in the commission of offenses and that some offenses are more clearly group activity than others.

Our classification of boys into conforming and delinquent subgroups accounts in large part for the selection of close friends who commit delinquent acts similar to one's own. While career-oriented delinquent boys generally have the highest proportion of triads where boys commit the same kind of delinquent act, they also have the highest overall rate of delinquency for each kind of act. The main problem is to account for the higher rate of delinquency among these boys. Certainly the effect of one's close friends on delinquency does not appear to be a sufficient reason to account for this higher rate since a substantial minority of careeroriented delinquent boys are in close friendship triads where at least one other boy does not commit the same kind of offense and the convergence of boys who commit the same kind of delinquent act in close friendship triads is not greater than that one would expect from the rate of delinquency among these boys.

This study cannot be construed as a test of the genetic formulation of the differential association hypothesis. To the extent that the findings of this study are valid and our logical inferences correctly drawn, however, they may be disappointing to proponents of differential association theory. The association of boys with the same kind of delinquent behavior in close friendship triads while somewhat grcater than chance is well below what 
one would expect from the learning hypothesis in differential association theory and the results are not independent of social class. Close friendship choices are more closely correlated with delinquency por se than with participation in specific patterns of delinquency presumably learned from others.

The results also cannot be interpreted as clearly supporting one of the major theories of delinquent behavior over that of another, though some postulates in these theories seem supported over others. The main sociological theories of subcultural delinquency such as those of Cohen and Walter Miller postulating differences between lower and middle class gang behavior find some support in this study. Delinquency among middle class boys, particularly for the more serious delinquent offenses, is independent of friendship choices while among lower class boys the probability of committing any kind of delinquent activity is related to the delinquent activity of one's close friends. The fact that selection of close friends who commit specific kinds of delinquency within each type of conformingdelinquent group is largely a function of the rate of delinquency within each group lends support to Walter Miller's contention that delinquency is endemic in lower class culture. Nonetheless, if Miller is correct, convergence of delinquent patterns of behavior in friendship groups should not exceed chance since he argues that the pressures toward deviance come from outside the immediate peer group. The fact that the probability of a lower class boy's committing any specific kind of delinquency is dependent upon the commission of the act by other members of the group therefore is at odds with Miller's formulation. The model of differential association seems even a less powerful one in accounting for our observed patterns of behavior in close friendship triads than does Miller's formulation, however.

The fact that a substantial proportion of career-oriented delinquent boys do show a marked similarity in delinquent activity, particularly for the more serious offenses, is consistent with Cohen's formulation emphasizing the versatility of delinquency among subcultural delinquents. That some of these groups may be specialized in specific kinds of delinquent activity was not investigated.

This study perhaps only serves to emphasize the difficulty in testing inferences from differential association theory. It perhaps is unnecessary to repeat what is already well stated, that we need to operationalize the hypothesis in such a way as to test the relationship of association with delinquent others through time. Of considerable importance, however, in future research would be an investigation of the "deviant" cases which do not conform to expectations of the differential association model. How can one account for the fact that all members of delinquent groups do not conform to the same patterns of delinquency? Why are some members of close friendship groups delinquent and not others? What are the patterns of recruitment to peer groups and how stable is peer group structure? 